\title{
A systematic review of stem cell therapy treatment for women suffering from stress urinary incontinence
}

\author{
Hadar Klapper-Goldstein ${ }^{1}$, Shai Tamam ${ }^{1}$, and Adi Weintraub ${ }^{1}$ \\ ${ }^{1}$ Soroka University Medical Center
}

May 5, 2020

\begin{abstract}
Objective: Stress urinary incontinence is a common health problem, with grave social and economic consequences, that is associated with a reduced quality of life. Stem cell therapy has developed as a novel modality for regeneration of injured tissues and could be a promising strategy for treatment of stress urinary incontinence. The objective of this systematic review is to summarize the clinical trials available to date, on stem cells therapy for treatment of stress urinary incontinence in woman. Study design: PubMed, Cochrane Library, Scopus and Embase were searched for studies published until January 2020 on Stem cell therapy for Stress urinary incontinence in woman. Quality of the included studies was assessed formally and independently by two authors using the JBI Critical Appraisal Checklists according to the PRISMA guidelines. Results: 19 studies were included and their quality was assessed with the JBI Critical Appraisal Checklists. These studies imply that stem cells therapy for treatment of stress urinary incontinence is a safe and effective treatment. Conclusions: While it is difficult to draw specific conclusions, initial results of stem cell therapy for the treatment of stress urinary incontinence seem encouraging. The great variability in cell types, injection protocols, follow up duration and evaluation tests, outcome measures and adverse effects indicates the need for standardization and validation of this treatment modality before it could be recommended for routine use.
\end{abstract}

\section{Hosted file}

BJOG Stem cell therapy for stress urinary incontinence V1.docx available at https: //authorea.com/users/307134/articles/438123-a-systematic-review-of-stem-cell-therapytreatment-for-women-suffering-from-stress-urinary-incontinence

\section{Hosted file}

Figure 1 for editing-Study selection process.pptx available at https://authorea.com/users/ 307134/articles/438123-a-systematic-review-of-stem-cell-therapy-treatment-for-womensuffering-from-stress-urinary-incontinence 